\title{
Living in Limbo: The Buddha of Suburbia and The Final Passage*
}

\author{
Jenny M. Djundjung
}

\begin{abstract}
Karim and Leila live between two cultures that are considered to be in two polar opposites, the cultures of the white and the black. Because of their parentage, they belong to both cultures and yet they do not belong to either one. The white British regards Karim as "the other", but he also regards an India born Indian to be "the other". Whereas Leila, is also regarded as "the other" in the Caribbean village where she grew up and yet, when she has immigrated to London, she regards the other Caribbean immigrant as "the other". This means that both of them have shifted their position from "the other" to "the self" in their attempt to find a place where they belong. The feeling of not belonged, puts them in a state of limbo; a state that is loaded with anxieties, questions and conflicts as they are unable to find an anchor that they can grip on.
\end{abstract}

Keywords: binary oppositions, Levi-Strauss, "the self", "the other", a state of limbo, "whiteness", "blackness", ethnicity, identity, margin to center.

The two novels, The Buddha of Suburbia_by Hanif Kureishi and The Final Passage by Caryl Phillips, narrate how the main characters, Karim and Leila, find themselves to be at the edge of the two cultures in which they were born. They are different and they feel different as the consequence of being born and raised in between two cultures. Karim has a middle-class English mother and an educated Indian father and Leila is born from her mother's relation with her "three" white fathers. Both of them never feel fully accepted in either culture, yet they can never abandon one and choose the other with which to fully identify. As a consequence, they are torn between the boundaries of the two polar opposites. They are ambivalent and keep sliding in and out the two cultures, which are positioned in two polar opposites.

In Levi-Strauss's view, culture is constructed of binary oppositions - pairs that give each other value in that one is what the other is not, such as male/female, self/other, central/marginal (Selden, 1986, p. 55). Each binary is seen as dichotomies that one negates the other and more dominant to the other. In the binary of male/female, male has value because it is not female but the concept cannot be applied the other way around. The rigid boundaries between what one is and what one is not (Eagleton, 1985, p. 133), becomes problematic when the concept is used to categorize a person. Using this concept, it is described that when a person is a male therefore the person is not a female,

\footnotetext{
* This paper has been presented in The International Conference on British Literary and Cultural Studies: Decoding Contemporary Britain on March 16-19, 2001 at Guangdong University of Foreign Studies, Guangzhou, China.
} 
'Yeah,' I said sullenly.'

'We don't want you blackies coming to the house.' 
'Many what you little coon?'

'Blackies.'

'Where?'

'Coming to the house?'

'We don't like it,' Hairy Back said. 'However many niggers there are, we don't like it. We're with Enoch. If you put one of your black 'ands near my daughter I'll smash it with a 'ammer! With a 'ammer!' (p. 40)

To protect himself from the hostility and to maintain his pride, he acts as if Hairy Back's reference of his blackness as something insignificant. In pretending not to understand that the reference is meant as an insult he can ask questions which are taken as a sign of his ignorance. He acts the way it is expected of him, a "dumb blacky". By falling into the stereotype he can get back at Hairy Back by making fun of him and provoke his anger without Hairy even realizing that Karim is doing so. His refusal to acknowledge the insult and his ability to turn the table of offending the offender puts him in the position of power. By doing so, Karim is able to keep his pride intact.

In yet another case, Karim is forced to act his Indian part to be able to get an acting job that he desires. During the interview, the director, Shadwell, tested his knowledge of the Indian culture by speaking to him in Punjabi or Urdu. When Karim failed the test, he regrets Karim's ignorance of the language or of the country. He suggested that Karim find his root by visiting India and reminding Karim that it is wrong for him to act like an Englishman, because it means that he is denying his heritage. In contrast to Hairy Back, Shadwell play the sympathetic role of a white who is compassionate to the problem that Karim is regarded as "a half-caste in England" and this must be hard for Karim "to accept belonging nowhere, wanted nowhere" (p. 141). When Karim refuses his sympathetic ears, he assigns Karim the role of Mowgli, the character in The Jungle Book.

'You're just right for him,' he [Shadwell] continued. 'In fact, you are Mowgli. You're dark skinned, you're small and wiry, and you'll be sweet but wholesome in the costume. Not too phonographic, I hope. Critics will go for you. Oh yes. Ha, ha, ha, ha, ha!' (pp. 142-3)

It turned out that on stage I would wear a loincloth and brown make-up, so that I resembled a turd in a bikini-bottom . . . But just when I was feeling at home in the loin-cloth and boot polish, and when I've learned my lines before anyone else and was getting as competent as a little orang-utan on the scaffolding, I saw that our conflicts hadn't ended. Shadwell took me aside and said, 'A word about the accent, Karim. I think it should be an authentic accent'. . .'Indian accents.'

'Karim, you have been cast for authenticity and not for experience.' (pp. 146-7)

As Karim is desperate to have his chance in acting, he has no choice but to do what is asked of him. He has been rejected because of his being the blacky, and his present job depends on his acknowledgement of his blackness. It is as if Shadwell is trying to make Karim to acknowledge his roots by pushing him to dress and to speak, what Shadwell considers, as the ways of the authentic Indian man. In a sense, Shadwell's treatment of Karim is similar to that of Hairy Back's in the ways that he treats Karim as "the other" by assuming that Karim shares the general problems of an immigrant. When giving Karim the role of Mowgli, he does not evaluate Karim on his talent and ability, but on his ethnicity. Karim's serious appeal to be spared from what Shadwell considers as 
authenticity reflects his resentment of the role he has to play because he is forced to reveal his Indian side which is identified with the child-animal character of Mowgli. The twofold humiliation he has to bear is because he is put in the position of the unfavourable stereotype of "the other" and that he can do nothing to escape the humiliation, as he is desperate for the job.

As Karim never feels himself to be black, it is not his blackness that hurts, but his pride. $\mathrm{He}$ is firm in his belief and view that he is an Englishman and no less an Englishman. Being the Englishman living in England, he puts "the real" Indian, Changez, in the position of "the other" and he positions himself as "the self". When he first sees Changez at the airport, his description is that of "[a] man walking towards England, towards our curious eyes" (p. 78). Karim's tone is the tone of an Englishman when he witnesses an Indian migrating to his country. He does not have the affinity with this Indian man, unlike Anwar who approves of Changez as his son-in-law right away because he is Indian. There is a strong sense of affinity and pride of one's root in Anwar's case as he always regards himself as Indian, so any Indian is better than any other man, that he "told Jamila [his daughter] what he'd decided: she was to marry the Indian and he would come over" (p. 57). Anwar's approval of Changez is based on the sentimental feelings he has of India, not of the man. Karim's delayed approval of Changez is based on Changez's kindness and "childish enthusiasm" when he concludes that Changez is "not so bad". Karim is shifting his position as "the self" in regarding "the other" by an objective observation of the man. He is unlike Hairy Back who judges a person from the colour of his skin and never makes the effort to know a person for who he is; or like Anwar who decides to accept a person because of his ethnicity and not because of the person. Hairy Back and Anwar are of a kind in having drawn the rigid lines in separating what can be considered as self and as other. Karim is positioning himself in between these two cultures where he belongs and does not belong to.

In The Final Passage, Leila was brought up to regard herself to be better than the other islanders that she is always considered to be somehow different. She is tolerated with the awe and respect reserved for a person of a higher social status that she is kept at a distance and would never be accepted as one of the villagers. Her marriage ceremony is more of a waited spectacle rather than a warm celebration.

The next day being Saturday Leila was married. But there was no string band, and nobody danced or sang in the street, and nobody walked with the wedding cake firmly balanced on their head. The service was as her mother had wanted it, strictly conventional, with Leila dressed from head to foot in a lacy white dress, large raindrop-like earrings in both her ears; and Michael looking smart in a dark blue suit, a white shirt and a tie . . . Michael was a poor boy from this village and he was marrying the mulatto girl from St Patrick's. He had done well for himself and they waited with anxiety. Even if it took all day they would wait; if nothing else, the marriage had been announced in heavy capitals in the Worker's Spokesman. (pp. 48-9)

Even though the whole village seems to be at the wedding, the traditional festivity accompanying a celebration like music, dances and laughter are absent. Her wedding is a solemn affair with everybody keeping very quite as if afraid that the noise they make would ruin the whole affair. They shake Leila's hand out of obligation that as soon as they have done so, "they just stood back and gazed at her" and "they would slip outside into the sun and talked there " (p. 50). Although it is the custom that all the villagers usually will take active parts in weddings among their own, in Leila's wedding, they 
become passive participants witnessing a grand wedding of one of their own, Michael, who has done very well in marrying a girl of a higher status who is not one of them. The villagers are not consciously excluding Leila; it is just that they have no idea on how to conduct themselves in the presence of someone not of their own. Whatever the reason, Leila is perceived as "the other" who is different.

Not only is Leila "the other" and different in her home island, she also encounters this attitude in England. She is regarded as an underprivileged that needs to be helped when she first arrived in England and "[a] woman in a Salvation Army uniform came towards Leila and offered her a cup of soup." Feeling offended, "Leila looked away, so the woman gave the soup to an old man; she watched over him as he drank it" (p. 145). Being regarded as an underprivileged is of course an alien experience to Leila who is used to living in comfort. She is not used to accept charity and her ignoring the soup is her silent protest of saying that she is not one of the coloured who will take charity, although it is all right for the old man to do so. Leila is shifting her position by excluding herself from the white concept of "the other" when she refuses the soup, but at the same time she agrees to this concept when she has no objection of the old man to accept the soup. She keeps a distance from the old man who is her fellow coloured immigrant.

Besides charity, Leila also has to deal with rejection in her effort to find a place for her family to stay. She experiences the humiliation of rejection because of being "the

They climbed the half dozen steps and Earl knocked loudly at the door. A white woman in her fifties, small, well-dressed and with her hair carefully brushed back, stood before the three adults and the child. She spoke first, giving them no time to state their business.

'I'm sorry, but it's only a small room . . .' She moved as if she was going to shut the door....

Earl continued to argue, but Leila turned and walked back down the steps. The woman's eyes followed her, and Leila now stood with her back to them, looking out across the road. As Earl began a new sentence the door slammed . . . but the rest of the signs were explicit. 'No vacancies for coloureds'. 'No blacks'. 'No coloureds'. Leila felt grateful for their honesty. (p. 156)

The implicit rejection is more humiliating, as Leila has no choice but to experience the rejection thrown to her face and even though as humiliating, the explicit rejection spares her the experience. Compared to Earl who seems not to be bothered by the rejection like the old man who accepts the charity, Leila is bothered by the charity and the rejection. She protests against these attitudes by choosing to ignore the offenders. She is stating her position of being at the periphery of the two worlds that she obviously does not belong to. Breaking the boundaries places her in neither positions in the accepted binaries of white/black or self/other. She is setting her position in the space in between the two worlds where she belongs to and does not belong to.

Both Karim and Leila cannot escape the definitions of their "blackness" in terms of "whiteness". Both worlds and cultures they share and do not share, and are unable to come to term with differences. Acceptance is based on ethnicity rather than the person. They "challenge(s) the fixed binaries which stabilize meaning and representation and show how meaning is never finished or completed, but keeps on moving to encompass other additional or supplementary meanings" (Hall, 1990, p. 229). Karim's come back to London from America and he gets a job as an actor in a soap opera, playing "the 
rebellious student son of an Indian shopkeeper", will make him famous all over the country. He has moved from America to London that has always become his center, the essence of his being. It is the place where he is among friends who accept him as a person with his uniqueness. Karim may always get a role as an Indian; and he cannot change his appearance because it is an integral part of who he is. From an unknown actor he has climbed up the ladder to fame because he is both an Indian and an English. He looks into the future thinking "what a mess everything had been, but that it wouldn't always be that way" (p. 284). He acknowledges his being who he is and comes to term with his difference.

Whereas Leila decides to go back to her island because "England, in whom she had placed so much of her hope, no longer held for her the attraction of her mother and new challenges. At least the small island she had left behind had safety and two friends" ( $p$. 203). Leila chooses the best of the two worlds she has come to know, leaving Michael behind, and conscious of the consequences of her decision. England that is supposed to excel in its cultures and tradition cannot provide for Leila's needs of safety and friendship. Leila finds her center in the little island that she has left behind. It is only after her journey that she is able to find herself to belong more to the island, where she can find friendship and safety.

Yet it is a need for every person "to find some ground, some place, some position on which to stand" as they have been "blocked out and refused an identity and identification within the majority nation" (Hall, 1991, p. 52). Karim and Leila need to find a place and position in which they fit, as they have been displaced not because of their voluntary choice, but of a condition they have to accept, acknowledge and to come to term with. Both Karim and Leila have moved from their marginal and confusing position to the center. Their center might not be the center for others. Their center is not a place free of problems and anxieties. Their center is not the place that is based on general definitions. Yet, their center is the place that can provide for their needs. It is a place where they are acknowledged as themselves, where they have significant role in the lives of their families and friends and where they find the essence of their being. Their center is their ground, place and position on which they stand and put their anchor. Their center is exactly the place that they first abandon, dislike and come back to; and it is the place that they have put their roots and anchor.

\section{References}

Baldick, Chris. (1996). Criticism and Literary Theory: 1890 to the Present. London and New York: Longman.

Eagleton, Terry. (1985). Literary Theory: An Introduction. Minneapolis: University of Minnesota Press.

Fokkema, D.W. and Kunne-Ibsch, Elrud. (1998). Teori Sastra Abad Kedua Puluh. Jakarta: PT Gramedia Pustaka Utama.

Hall, Stuart. (1990). "Cultural Identity and Diaspora." Identity: Community, Culture, Difference. Ed. John Rutherford. London: Lawrence and Wishart. 
(1991). "Old and New Identities, Old and New Ethnicities". Culture, Globalization and the World System: Contemporary Conditions for the Representation of Identity. Ed. Anthony D. King. London: Macmillan.

Kureishi, Hanif. (1999). The Buddha of Suburbia. Great Britain: Faber and Faber.

Phillips, Caryl. (1995). The Final Passage. London: Picador.

Selden, Raman. (1986). A Reader's Guide to Contemporary Literary Theory. Kentucky: The UP of Kentucky.

(1989). Practicing Theory and Reading Literature: An Introduction. Great Britain: The UP of Kentucky.

Scholes, Robert. (1974). Structuralism in Literature: An Introduction. New Haven and London: Yale UP.

Walder, Dennis. (1998). Post-Colonial Literatures in English: History Language Theory. Malden, Massachusettes and Oxford: Blackwell Publishers. 